\title{
Effect of prolactin on the LH response to synthetic LH-RH in ovariectomized ewes
}

\author{
W. A. Chamley* \\ Reproduction Research Section, University of Melbourne, S.S. Cameron Laboratory, \\ Werribee, Australia 3030
}

Summary. When ovariectomized ewes were treated with LH-RH, all 3 receiving prolactin infusion and 4 out of 5 receiving an infusion of $\mathrm{NaCl}$ solution responded.

\section{Introduction}

In the ewe, parturition is preceded by a fall in progesterone and a sharp rise in unconjugated oestrone and oestradiol-17 (Bedford, Challis, Harrison \& Heap, 1972; Chamley et al., 1973). When similar changes in the circulating levels of these steroids take place at the time of oestrus (Moore et al., 1969; Chamley et al., 1972), there is a surge release of LH and FSH (Salamonsen et al., 1973). There is, however, no release of LH at the time of parturition (Chamley et al., 1973).

In pregnant ewes there is a progressive decrease in the $\mathrm{LH}$ response to synthetic $\mathrm{LH}-\mathrm{RH}$ as term approaches (Chamley, Findlay, Cumming, Buckmaster \& Goding, 1974; Jenkin \& Heap, 1974). Similar findings for lactating ewes (Pelletier \& Thimonier, 1973; Pant, Hopkinson \& Fitzpatrick, 1973) led to the suggestion (Pant et al., 1973) that this lack of response to LH-RH might be due to the high prolactin levels then circulating (Fell et al., 1972). The present study was carried out to determine whether large doses of prolactin affect the LH response to LH-RH ovariectomized ewes.

\section{Materials and Methods}

Two experiments were performed in a closed shed with Merino ewes which were penned individually and allowed access to food and water at all times. In Exp. I, the normal pattern of circulating prolactin at about the time of parturition was recorded for 6 ewes. The results were used as a basis for the calculation of infusion rates for the prolactin preparation used in Exp. II.

The 8 animals in Exp. II (see Table 1) had been bilaterally ovariectomized at least 2 months earlier. Three animals received a 4-day infusion of ovine prolactin (NIH-P-S11 dissolved in 0.154 M-NaCl solution) into one jugular vein, and the other 5 served as controls and were similarly infused with $0.154 \mathrm{M}-\mathrm{NaCl}$ solution only. The rate of infusion was $1.6 \mathrm{ml} / \mathrm{h}$. For animals receiving prolactin, the dose rate remained constant during each $24 \mathrm{~h}$ but was increased on successive days (Table 1) to try and simulate the prolactin level pattern observed in Exp. I. The dose rates were determined from the Exp. I results, from the immunological potency of the prolactin preparation, as determined by radioimmunoassay of a known amount of this prolactin in the plasma from an hypophysectomized ewe, and from published data on metabolic clearance rate (MCR) for prolactin in the lactating ewe, using a value for MCR of $150 \mathrm{ml} / \mathrm{min}$ (Davis \& Borger, 1973). On the 4th day of the infusion period, all animals received an intravenous injection of $20 \mu \mathrm{g}$ synthetic $\mathrm{LH}-\mathrm{RH}$ (Hoechst) given in $10 \mathrm{ml} 0.154 \mathrm{M}-\mathrm{NaCl}$ solution.

In both experiments, $10-\mathrm{ml}$ blood samples were withdrawn from a jugular vein which had been cannulated with silastic tubing at least 1 day before the start of the experiment. In Exp. I, sampling was started at least 3 days before parturition and blood samples were taken every $6 \mathrm{~h}$ up to the time of parturition. In Exp. II, three blood samples were collected between 09:00 and 11:30 h on each of the days when prolactin or $\mathrm{NaCl}$ solution was being infused (i.e. Days -3 to -1 ). On the day of LH-RH treatment (Day 0), samples were collected at intervals of 10,20 and/or 60 min during and after LH-RH

* Present address: Pacific Biomedical Research Center, University of Hawaii, 1993 East West Road, Honolulu, Hawaii 96822, U.S.A. 
injection (see Text-fig. 1). The heparinized blood samples were immediately centrifuged and the plasma stored at $-12^{\circ} \mathrm{C}$ until assay.

Prolactin was measured by a solid-phase radioimmunoassay (Fell et al., 1972). Under the assay conditions used, non-specific binding of ${ }^{125} \mathrm{I}$-labelled prolactin was $<10 \%$ of the counts bound to antibody at the zero point of the standard curve. The antibody showed no cross-reaction with purified ovine LH and a $2 \%$ cross-reaction with ovine growth hormone (NIH-GH-S8) (Fell et al., 1972). All samples were measured within a range on the standard curve where the within-assay coefficient of variation was $<10 \%$. This required repeated assay of some samples after appropriate dilution with $0.01 \mathrm{M}-$ sodium phosphate buffer, $\mathrm{pH} 7 \cdot 4$. The between-assay coefficient of variation did not exceed $16 \%$. The sensitivity was $2 \mathrm{ng} / \mathrm{ml}$.

LH was measured by a solid-phase radioimmunoassay (Goding et al., 1969). Nonspecific binding was $<5 \%$ and the antibody showed no cross-reaction with ovine prolactin or ACTH. Cross-reactions with ovine growth hormone and FSH were $<1 \%$ and $2 \%$ respectively. All samples were measured so that values fell on the standard curve between 1 and $10 \mathrm{ng} / \mathrm{ml}$ and over this range the within-assay coefficient of variation was $<10 \%$. The between-assay coefficients of variation at 1.6 and $11.3 \mathrm{ng} / \mathrm{ml}$ were $19 \cdot 3$ and $11.4 \%$ respectively.

A basal hormone level was calculated as the mean of the pretreatment values. Individual $\mathrm{LH}$ responses to LH-RH were plotted and the points connected by straight lines so that the hormone response could be calculated as the area between each response curve and the respective basal level up to $330 \mathrm{~min}$ (Hooley et al., 1974). Differences in response areas and/or means were tested for significance by Student's $t$ test (Snedecor \& Cochran, 1968).

\section{Results}

In Exp. I prolactin concentrations in the 6 ewes were at or below the limit of sensitivity of the assay until 3 days before parturition. On Days $-3,-2$ and -1 the mean ( \pm s.e.m.) prolactin concentrations were $9 \cdot 6 \pm 3 \cdot 1(n=21), 55 \cdot 5 \pm 14 \cdot 4(n=23)$ and $230 \cdot 8 \pm 26 \cdot 5(n=27) \mathrm{ng} / \mathrm{ml}$, respectively.

The infusion of relatively large amounts of ovine prolactin into ovariectomized ewes (Exp. II) caused no significant change in the level of LH during the 3 days before treatment with LH-RH. There was no significant change in control ewes which received saline (Text-fig. 1) and mean daily LH levels in the two treatment groups were similar (Table 1, Text-fig. 1). An LH response to LH-RH occurred in the 3 ewes treated with prolactin and in 4 of the 5 controls (Text-fig.1 ). For the responding ewes, the area units were $3693 \pm 1545$ (s.d.) for the saline-treated animals and $4273 \pm 1185$ for the prolactin-treated animals $(P<0.01)$.

\section{Discussion}

These experiments were carried out to gain further insight into the underlying reasons for the anovulatory post-partum condition in sheep. Parturition was preceded by a sharp rise in prolactin secretion

Table 1. Details of prolactin dose rates and pretreatment LH levels in ovariectomized ewes receiving a continuous infusion of ovine prolactin ( 3 ewes) or $0.154 \mathrm{M}-\mathrm{NaCl}$ solution ( 5 ewes)

\begin{tabular}{ccccc}
\hline & \multicolumn{2}{c}{ Prolactin infusion } & & $\mathrm{NaCl}$ infusion \\
\cline { 2 - 3 } $\begin{array}{c}\text { Days relative } \\
\text { to LH-RH } \\
\text { treatment }\end{array}$ & $\begin{array}{c}\text { Dose rate } \\
(\mathrm{mg} / \text { day })\end{array}$ & $\begin{array}{c}\text { Pretreatment } \\
\text { LH } \\
(\mathrm{ng} / \mathrm{ml})\end{array}$ & & $\begin{array}{c}\text { Pretreatment } \\
\text { LH } \\
(\mathrm{ng} / \mathrm{ml})\end{array}$ \\
\hline-3 & 2.1 & $4.4 \pm 2.9$ & & $5.0 \pm 3.3$ \\
-2 & 12.0 & $4.8 \pm 3.0$ & & $5.9 \pm 1.6$ \\
-1 & 49.9 & $6.6 \pm 2.8$ & & $6.8 \pm 1.1$ \\
0 & 49.9 & $6.7 \pm 5.8$ & & $3.6 \pm 0.9$ \\
\hline
\end{tabular}

Values are mean \pm s.d. 


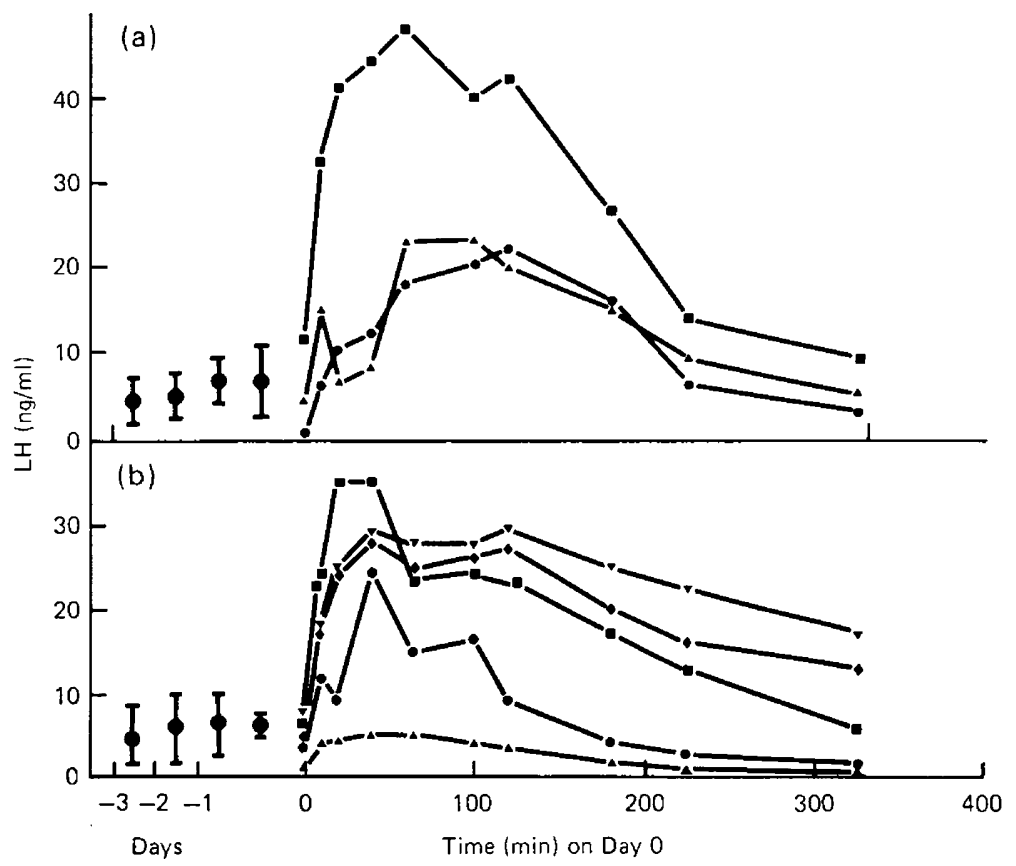

Text-fig. 1. Mean LH levels for ovariectomized ewes receiving (a) prolactin or (b) NaCl solution over a 3-day period before treatment with $20 \mu \mathrm{g}$ LH-RH on Day 0 . Before Day 0 the mean $\pm s . d$. is given for all the animals ( 3 in a, 5 in b); thereafter each is represented separately. The dose of prolactin given on each day is shown in Table 1.

as reported by others (McNeilly, 1971; Fell et al., 1972), but the results of Exp. II show that the presence of circulating prolactin had no effect on the LH response of ovariectomized ewes given LH-RH.

A significant rise in tonic secretion of $\mathrm{LH}$ occurs by 15 days after castration (Roche, Foster, Karsch \& Dziuk, 1970). Ovariectomized ewes were used for Exp. II in the present study so that pretreatment levels were detectable and the magnitude of the LH response could be more accurately determined. This model cannot, of course, be equated with the late pregnant ewe which experiences many hormone changes at parturition (Chamley et al., 1973), but it is clear that prolactin, when infused at rates approximating those measured at parturition, failed to block the pituitary response to LH-RH and the suggestion of Pant et al. (1973) cannot be supported.

The financial support of the Australian Wool Research Trust Fund and provision of facilities by the Director of Agriculture, Victoria, are gratefully appreciated.

\section{References}

Bedford, A., Challis, J.R.G., Harrison, F.A. \& Heap, R.B. (1972) The role of oestrogens and progesterone in the onset of parturition in various species. $J$. Reprod. Fert., Suppl. 16, 1-23.

Chamley, W.A., Buckmaster, J.M., Cain, M.D., Cerini, J.M., Cerini, M.E., Cumming, I.A. \& GodING, J.R. (1972) The effect of prostaglandin $F_{2 x}$ on progesterone, oestradiol and luteinizing hormone secretion in sheep with ovarian transplants. J. Endocr. $55,253-263$.
Chamley, W.A., Buckmaster, J.M., Cerini, M.E., Cumming, I.A., Goding, J.R., Obst, J.M., Williams, A. \& Winfield, C. (1973) Changes in the levels of progesterone, corticosteroids, estrone, estradiol-17 $\beta$, luteinizing hormone and prolactin in the peripheral plasma of the ewe during late pregnancy and at parturition. Biol. Reprod. 9, 30-35.

Chamley, W.A., Findlay, J.K., Cumming, I.A., BUCKMASTER, J.M. \& GodING, J.R. (1974) Effect of pregnancy on the LH response to synthetic gona- 
dotropin releasing hormone. Endocrinology 94, 291293.

DAVIS, S.L. \& BORGER, M.L. (1973) Metabolic clearance rates and secretion rates of prolactin in sheep. Endocrinology 92, 1414-1418.

Fell, L.R., BeCK, C., Brown, J.M., CatT, K.J., Cumming, I.A. \& Goding, J.R. (1972) Solid-phase radioimmunoassay of ovine prolactin in antibodycoated tubes. Prolactin secretion during estradiol treatment, at parturition and during milking. Endocrinology 91, 1329-1336.

Goding, J.R., CatT, K.J., Brown, J.M., Kaltenbach, C.C., Cumming, I.A. \& Mole, B.J. (1969) Radioimmunoassay for ovine luteinizing hormone. Secretion of luteinizing hormone during estrus and following estrogen administration in the sheep. Endocrinology 85, 133-142.

Hooley, R.D., BaXter, R.W., Chamley, W.A., Cumming, I.A., Jonas, H.A. \& FindlaY, J.K. (1974) FSH and LH response to gonadotropin-releasing hormone during the ovine estrous cycle and following progesterone administration. Endocrinology 95, 937942.

JENKIN, G. \& HEAP, R.B. (1974) The lack of response of the sheep pituitary to LH-releasing hormone stimulation in gestation and early lactation: the probable role of progesterone. J. Endocr. 61, xii.

MOORE, N.W., BARRETT, S., BROWN, J.B., SCHINDleR, I.,
SMITH, M.A. \& SMYTH, B. (1969) Oestrogen and progesterone content of ovarian vein blood of the ewe during the oestrous cycle. J. Endocr. 44, 55-62.

MCNEILLY, J.R. (1971) A solid phase radioimmunoassay for ovine prolactin. $J$. Endocr. 49, 141-149.

Pant, H.C., Hopkinson, C. \& FitzPatrick, R.J. (1973) Suppression of $\mathrm{LH}$ release induced by luteinizing hormone releasing hormone (LH-RH) in ewes during lactation. Acta endocr., Copenh., Suppl. 177, 298, Abstr.

Pelletier, J. \& Thimonier, J. (1973) Comparison of induced preovulatory $\mathrm{LH}$ discharge in lactating and dry sheep during seasonal anoestrus. J. Reprod. Fert. 33, 310-313.

Roche, J.F., Foster, D.L., KARSCh, F.J. \& DziUK, P.J. (1970) Effect of castration and infusion of melatonin on levels of luteinizing hormone in sera and pituitaries of ewes. Endocrinology 87, 1205-1210.

Salamonsen, L.A., Jonas, H.A., Burger, H.G., Buckmaster, J.M., Chamley, W.A., Cumming, I.A., FINDLAY, J.K. \& GodING, J.R. (1973) A heterologous radioimmunoassay for follicle-stimulating hormone: application to measurement of FSH in the ovine estrous cycle and in several other species including man. Endocrinology 93, 610-618.

SNedecor, G.W. \& Cochran, W.G. (1968) Statistical Methods, 6th edn, p. 120. Iowa State University Press, Ames.

Received 7 July 1977 